\title{
Patch-Clamp Recordings from Cerebellar Basket Cell Bodies and Their Presynaptic Terminals Reveal an Asymmetric Distribution of Voltage-Gated Potassium Channels
}

\author{
Andrew P. Southan and Brian Robertson \\ Electrophysiology Group, Department of Biochemistry, Imperial College of Science, Technology and Medicine, London \\ SW7 2AY, United Kingdom
}

\begin{abstract}
Cerebellar basket cells form highly specialized inhibitory synaptic contacts with Purkinje cells, namely the pericellular basket and pinceau nerve terminal structures, wrapping around the Purkinje cell somatic and axon hillock regions. These inhibitory synaptic contacts are ideally located to control the ultimate output of the cerebellar cortex. Previous immunohistochemical studies have shown that these synaptic structures possess a very high density of the dendrotoxin (DTX)-sensitive potassium channel subunit, Kv1.2. We have taken advantage of this unique anatomical arrangement offering a high concentration of identified Kv channel subunits by combining whole-cell patch-
\end{abstract}

clamp recording and fluorescence microscopy to establish a novel preparation and perform the first recordings from unambiguously identified mammalian CNS inhibitory presynaptic terminals. We report that DTX-sensitive potassium channels are present in basket cell terminals but not in the basket cell soma. This selective cellular distribution suggests that these channels play an important role in modulating cerebellar inhibitory synaptic transmission.

Key words: potassium channels; cerebellum; synapse; whole cell; electrophysiology; mouse
A crucial task in neurobiology is to describe the electrical behavior of central neurons in terms of their molecular components. Fortunately, we have a wealth of information on the properties of cloned channels in expression systems (Chandy and Gutman, 1995), and neuroanatomical studies have revealed disparate distributions of identified channel subunits both between populations and also within central neurons. Most detail is available for voltage-gated potassium $(\mathrm{Kv})$ channels and their accessory subunits (Sheng et al., 1992, 1994; McNamara et al., 1993, 1996; Vega-Saenz de Miera et al., 1994; Wang et al., 1994; Weiser et al., 1994; Rhodes et al., 1995, 1996; Veh et al., 1995). Nevertheless, studies seeking direct correlations between identified channel subtypes and physiological roles (e.g., neurotransmitter release) are still in their infancy. This is especially the case for mammalian central synapses, where their small size usually precludes electrophysiological recording. Direct studies of mammalian synapses are currently restricted to the "giant" glutamatergic terminal at the calyx of Held (Forsythe, 1994; Borst et al., 1995; Borst and Sakmann, 1996). Here we examine Kv channels in cerebellar basket cells in the cell soma and in their distinctive inhibitory presynaptic terminals around Purkinje cells. Our investigation is driven by a number of considerations, namely the need to compare native $\mathrm{Kv}$ channels with their biophysical and pharmacological profiles in expression systems and to examine the properties of ion channels in a more typically sized CNS terminal.

From all possible inhibitory inputs (including stellate cells and recurrent collaterals), basket cells provide the major inhibitory drive to Purkinje neurons (Andersen et al., 1963; Eccles et al.,

Received Sept. 16, 1997; revised Oct. 30, 1997; accepted Nov. 17, 1997.

This work was supported by the Wellcome Trust (045812).

Correspondence should be addressed to Dr. Brian Robertson, Electrophysiology Group, Department of Biochemistry, Imperial College of Science, Technology and Medicine, London SW7 2AY, UK.

Copyright (C) 1998 Society for Neuroscience $\quad 0270-6474 / 98 / 180948-08 \$ 05.00 / 0$
1967; Palay and Chan-Palay, 1974). Ramón y Cajal (1911) first described the unique nature of basket axon collaterals, which form synaptic contacts directly on cell bodies and to a lesser extent on axon hillocks ("pinceau") of Purkinje cells (Palay and Chan-Palay, 1974). Purkinje cells are the sole efferent output of the cerebellar cortex, and because the axon initial segment is the region of action potential generation (Andersen et al., 1963; Stuart and Hausser, 1994), these synaptic terminations are strategically located to control the final output of Purkinje cells.

Specific antibody labeling has revealed that basket cell pinceaux express the highest level of Kv1.2 channels in the brain (McNamara et al., 1993, 1996; Wang et al., 1993, 1994; Sheng et al., 1994). There is also immunoreactivity against Kv1.1 channels in the pinceau region (Wang et al., 1994; Veh et al., 1995; Laube et al., 1996), suggesting that Kv1.1 and Kv1.2 assemble into heteromultimeric complexes. Kv3.4 $\alpha$-subunits (Veh et al., 1995; Laube et al., 1996), accessory Kv $\beta 2.1$ subunits (Rhodes et al., 1995), and the Kv1-anchoring protein SAP-90 (Kistner et al., 1993; Laube et al., 1996) are selectively localized to basket cell terminations. This very high density of known Kv channels in a well defined anatomical location offers a unique opportunity for a detailed electrophysiological study of their properties and role in the mammalian brain.

\section{MATERIALS AND METHODS}

Preparation and solutions. Basket cells develop connections after postnatal day 8 in the rat and mouse (Altman, 1982; Z hang and Goldman, 1996) and additional ultrastructural changes occur up to 3 weeks postnatally (Larramendi, 1969). Therefore, 3- to 5-week-old male mice (TO strain; Charles River Laboratories, Wilmington, MA) were used throughout this study. The cerebellum was dissected out immediately after cervical dislocation and decapitation and rapidly immersed in a chilled $\left(\sim 4^{\circ} \mathrm{C}\right)$ modified artificial cerebrospinal fluid (ACSF) solution for 3-5 min. This modified solution, used only during dissection and slice preparation, differed from the normal ACSF by isosmotic substitution of sodium chloride with sucrose. Sagittal slices $(250 \mu \mathrm{m})$ of cerebellum were then 
prepared using a Campden Vibroslice (Campden Instruments). Slices were subsequently incubated at room temperature $\left(20-25^{\circ} \mathrm{C}\right)$ and fully submerged in the normal ACSF comprising (in $\mathrm{mM}$ ): $124 \mathrm{NaCl} ; 26$ $\mathrm{NaHCO}_{3} ; 3 \mathrm{KCl} ; 2 \mathrm{MgSO}_{4} ; 2.5 \mathrm{NaH}_{2} \mathrm{PO}_{4} ; 2 \mathrm{CaCl}_{2} ; 10$ glucose, $\mathrm{pH}$ 7.3-7.4, gassed continually with $95 \% \mathrm{O}_{2} / 5 \% \mathrm{CO}_{2}$.

Cerebellar slices were placed in a custom-made glass-bottom recording chamber (volume $0.5 \mathrm{ml}$ ) and secured by a fine nylon mesh attached to a small platinum wire hoop. Individual neurons were visualized with an Axioskop FS microscope (Carl Zeiss) with water immersion lenses $[63 \times / 0.9$ numerical aperture $(\mathrm{NA}) ; 100 \times / 1.0 \mathrm{NA}], 16 \times$ magnification eyepieces, and differential interference contrast (DIC) optics. All recordings reported here were made at room temperature from slices perfused with standard ACSF at $3-5 \mathrm{ml} / \mathrm{min}$.

Recording techniques. Patch electrodes were made from filamented thick-wall electrode glass (GC150F-10; Clark Electromedical Instruments, Pangbourne, UK) using a PP83 microelectrode puller (Narashige, Tokyo, Japan). For whole-cell somatic recording, electrode resistance was typically 4-8 $\mathrm{M} \Omega$; the resistance of electrodes used for terminal recording was normally $\sim 12 \mathrm{M} \Omega$ (range, $10-15 \mathrm{M} \Omega$ ). The intracellular pipette solution contained (in $\mathrm{mM}$ ): $140 \mathrm{KCl}, 1 \mathrm{MgCl}_{2}, 1 \mathrm{CaCl}_{2}, 10$ EGTA, 10 HEPES, $\mathrm{pH}$ 7.4. For on-cell recording the pipette solution contained (in mM): $\mathrm{NaCl} 150, \mathrm{KCl} 2.8$, HEPES $10, \mathrm{CaCl}_{2}$ 1.0, $\mathrm{pH} 7.2$. For terminal recordings, slight positive pressure $(\sim 1 \mathrm{ml}$ depression on a $10 \mathrm{ml}$ syringe) was applied while the membrane was approached (this compares with $\sim 4 \mathrm{ml}$ depression for somatic recording); sealing was facilitated by gentle release of this pressure and application of slight negative pressure. All seals were at least $3 \mathrm{G} \Omega$ (range, 3-7 G $\Omega$ ); however, it frequently took longer to form gigaohm seals on terminals. Lucifer yellow $(1-4 \mathrm{mg} / \mathrm{ml}$ ) (dipotassium or dilithium salt; Sigma, Poole, UK) was added to all pipette solutions, enabling subsequent unambiguous identification of the recording site (Stuart et al., 1993; Forsythe, 1994).

Voltage-clamp recordings were made using an EPC9 amplifier (HEKA Elektronik). A Macintosh computer (Power PC 7500/100) running Pulse software (v7.89, HEKA) was used for data acquisition. Analysis was performed using Pulsefit (v7.89, HEKA), Axograph (v3.03, Axon Instruments, Foster City, CA), and Igor (v.2.04, Wavemetrics) software. Data were sampled between 4 and $24 \mathrm{kHz}$ after they were filtered at one third of the appropriate sampling frequency. Except where indicated, all current records are leak- and capacity-subtracted with a p-on-4 protocol. Somatic recordings from basket cells gave initial resting potentials between -55 and $-75 \mathrm{mV}$, mean input resistance of $685 \pm 78 \mathrm{M} \Omega(n=39)$, and whole-cell capacitance of $9.5 \pm 0.5 \mathrm{pF}(n=25)$. Mean series resistance for somatic recording was $18 \pm 1 \mathrm{M} \Omega(n=25)$, and $75-95 \%$ compensation was used (both variables were monitored continuously and adjusted as appropriate). Basket cell terminal resting potential and input resistance were $-72 \pm 3 \mathrm{mV}(n=10)$ and $1.0 \pm 0.3 \mathrm{G} \Omega(n=4)$, respectively. Terminal series resistance $(<30 \mathrm{M} \Omega)$ was monitored and compensated for (75-95\%) throughout. Somatic recordings from Purkinje cells yielded mean resting potential and input resistance values of $-56 \pm 2 \mathrm{mV}$ and $146 \pm 25 \mathrm{M} \Omega(n=3)$, respectively. Drug effects are quantified as percentage change in either current amplitude or the charge transferred $\left(Q_{\text {step }}\right)$ during the voltage step.

Basket cell images were captured using a TM 520 video camera (Pulnix), displayed on a Hitachi VM1720 TV monitor, and stored on video tape for subsequent analysis. Lucifer yellow fluorescence images were obtained after electrophysiological recording using a mercury short arc lamp (HBO 50, Carl Zeiss) and a blue-violet filter set (excitation wavelength 395-440 nm, Carl Zeiss). Images were captured using National Institutes of Health Image software (v.1.60; National Institutes of Health, Bethesda, MD), and montages were constructed by overlaying images captured at varying depths in the slice using Adobe Photoshop (v3.0.4, Adobe Systems). Charybdotoxin and $\alpha$-DTX were purchased from Alomone Labs (Jerusalem, Israel), apamin was purchased from Latoxan (Rosans, France), and toxin I and toxin K were a gift from John Stow (Wyeth Research, Taplow, UK). TTX and bicuculline were obtained from Sigma. All data are presented as mean \pm SEM, where $n=$ number of cells.

\section{RESULTS}

\section{Purkinje cell IPSC amplitude and frequency are increased by $\alpha$-DTX}

To determine whether the Kv1.1 and Kv1.2 channels identified by anatomical studies on basket cell terminations were functional, we made use of the selective Kv1.1 and Kv1.2 potassium channel
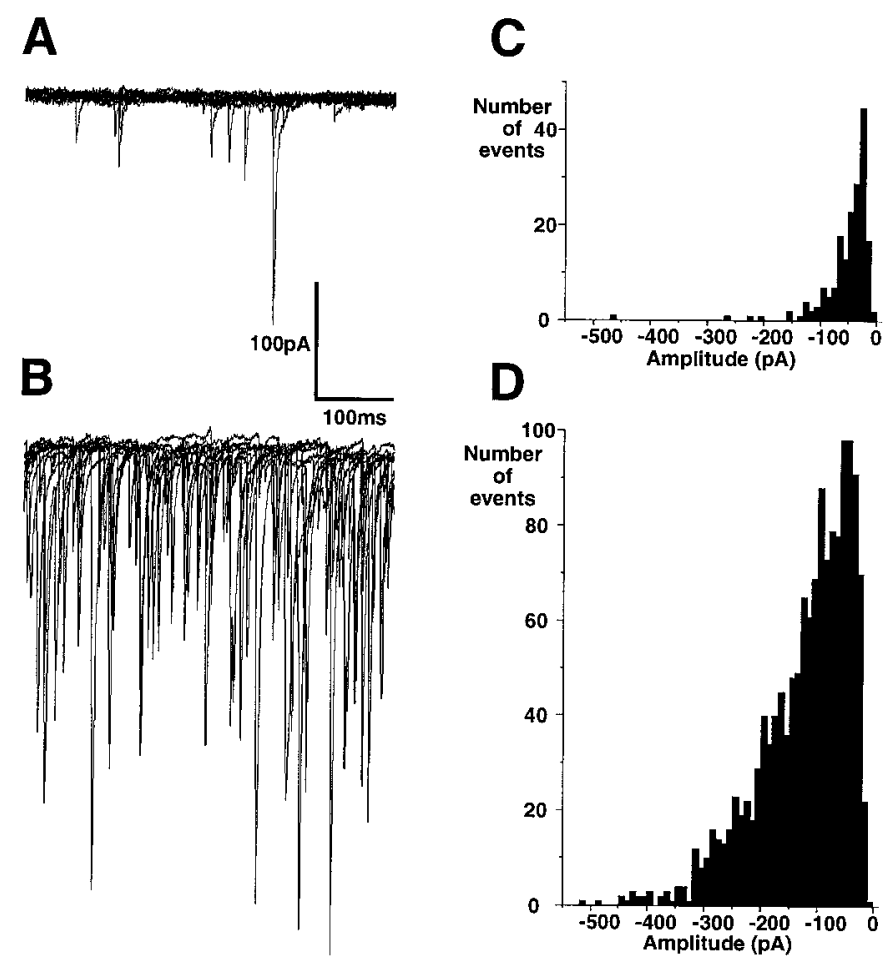

Figure 1. Effect of $\alpha$-DTX on spontaneous IPSCs recorded from a Purkinje cell. $A$, Typical Purkinje cell spontaneous IPSCs recorded in control solution ( $5 \mathrm{sec}$ sample). $B$, After a 3 min bath perfusion of $200 \mathrm{~nm}$ $\alpha$-DTX, both IPSC frequency and amplitude are enhanced significantly (5 sec sample). $C$, Amplitude histogram corresponding to the currents recorded in $A$. In a $45 \mathrm{sec}$ time period, control IPSC frequency and amplitude for this cell were $4.0 \mathrm{~Hz}$ and $47.6 \pm 3.6 \mathrm{pA}$, respectively. $D$, Amplitude histogram corresponding to the currents recorded in $B$. $\alpha$-DTX (200 nM) increased the frequency and amplitude to $31.4 \mathrm{~Hz}$ and $116.9 \pm 2.2 \mathrm{pA}$.

blocker $\alpha$-DTX (Stühmer et al., 1989). If these channels play a physiological role, then blockage of basket cell nerve terminal potassium channels with this toxin should result in increased neurotransmitter release onto Purkinje cells.

Somatic recordings from Purkinje cells, at a holding potential of $-70 \mathrm{mV}$ using high chloride-containing patch pipettes, revealed spontaneous synaptic events with a range of amplitudes between $<10$ and $750 \mathrm{pA}$. Virtually all of these events were blocked by bath application of bicuculline $(5 \mu \mathrm{M}, n=3)$ and were therefore characterized as spontaneous IPSCs mediated by $\mathrm{GABA}_{\mathrm{A}}$ receptor activation (Vincent et al., 1992). Bath application of $200 \mathrm{~nm} \alpha$-DTX rapidly (effects were apparent within 60 sec) increased both the mean IPSC amplitude and frequency to $-91.3 \pm 2.5 \mathrm{pA}$ and $27.3 \pm 9.7 \mathrm{~Hz}$ from their respective control values of $-49.7 \pm 1.2 \mathrm{pA}$ and $11.3 \pm 6.9 \mathrm{~Hz}$ (Fig. 1) $(n=3 ; p<$ 0.05 ). In a random sample of 40 IPSCs (amplitude $\sim 200 \mathrm{pA}$ ), the decay time constant was best fitted with a double exponential and was unaffected $(p>0.05)$ after application of $\alpha$-DTX. The mean values $\left(\tau_{1}\right.$ and $\left.\tau_{2}\right)$ were $4.3 \pm 0.2 \mathrm{msec}$ and $26.5 \pm 1.9 \mathrm{msec}$ in control and $4.2 \pm 0.3 \mathrm{msec}$ and $26.0 \pm 1.8 \mathrm{msec}$ in the presence of $200 \mathrm{~nm} \alpha$-DTX. The $10-90 \%$ rise time of these IPSCs was also unchanged by $200 \mathrm{~nm} \alpha$-DTX; mean values were $0.83 \pm 0.02 \mathrm{msec}$ in control and $0.82 \pm 0.01 \mathrm{msec}$ in $\alpha$-DTX.

These results suggest that $\alpha$-DTX-sensitive potassium channels play a role in regulating GABA release from basket cells. 
Figure 2. Basket cell morphology. Basket cell identity was confirmed by fluorescence imaging after loading with lucifer yellow during somatic recording. The montage illustrates a soma, part of the dendritic tree, and the axon, which emerges from the cell body, travels parallel to the Purkinje cell bodies, and drops descending collaterals which wrap around three Purkinje cell bodies contributing to the pericellular basket and pinceau structures. Scale bar, $10 \mu \mathrm{m}$.

\section{Anatomy of cerebellar basket cells}

Basket cell bodies are located in the lower third of the molecular layer of the cerebellum (Palay and Chan-Palay, 1974). The basket cell axon generally travels in one direction along the Purkinje cell layer, dropping collaterals to several Purkinje cells mainly on or near the cell soma that constitutes the unique pericellular basket and pinceau structures (Bishop, 1993) (see introductory remarks). We made use of this distinctive anatomy to confirm unambiguously all of the basket cell recordings presented here. Lucifer yellow loading during somatic recordings $(n=70)$ showed that labeled neurons typically had a dendritic tree extending across the molecular layer (often continuing $>150 \mu \mathrm{m}$ toward and along the pial surface), an ovoid soma $(\sim 10-15 \mu \mathrm{m}$ diameter) whose axon (extending up to $200 \mu \mathrm{m}$ away from the soma) gives rise to specialized collaterals that form pericellular basket and pinceau structures. Figure 2 shows a representative fluorescence image of a basket cell filled during somatic recording. In this example, the axon has dropped three collaterals that wrap around three Purkinje cell somata and form characteristic terminal plexuses seen in earlier anatomical studies. Inadvertent glial cell recordings were extremely rare $(n=5$ of 75$)$; such cells were easily identified and subsequently discounted from further study by their characteristic morphology (Palay and Chan-Palay, 1974; Müller et al., 1994) and lack of voltage-gated and synaptic conductances (Clark and Barbour, 1997).

\section{Pharmacology of the basket cell somatic potassium current}

Whole-cell recordings from basket cell somata revealed a transient, TTX-sensitive sodium current (threshold approximately $-55 \mathrm{mV}$ ), followed by a sustained, usually slowly inactivating potassium current (threshold approximately $-45 \mathrm{mV}$ ). To inves- tigate the pharmacology of the basket cell somatic potassium current, we bath-applied both broad spectrum (TEA, 4-AP) and more selective (toxin I, toxin $\mathrm{K}, \alpha$-DTX, apamin, charybdotoxin) potassium channel blocking agents during whole-cell recordings (Table 1). Somatic potassium currents were evoked by a $200 \mathrm{msec}$ depolarizing current step to $+30 \mathrm{mV}$ from a holding potential of $-90 \mathrm{mV}$, in normal ACSF supplemented with $1 \mu \mathrm{M}$ TTX. Substantial block of the evoked outward current was observed only with TEA (10 mM, $n=9$; $30 \mathrm{~mm}, n=7$ ) (Fig. $3 A)$; this block was extremely rapid in onset (within $10 \mathrm{sec}$ of solution change) and was usually fully reversible. 4-AP was ineffective in blocking somatic potassium current, despite the use of relatively high concentrations ( 1 and $5 \mathrm{~mm}, n=4)$ (Fig. $3 A$ ). At concentrations between 200 and $300 \mathrm{~nm}$, none of the dendrotoxins tested (toxin I, $n=4$; toxin $\mathrm{K}, n=4$; $\alpha$-DTX, $n=5$ ) had any significant effects on the somatic current (Fig. $3 A, B)$. Similarly, apamin $(n=3)$ and charybdotoxin $(n=4)$ did not block the outward current (Fig. $3 A$ ), suggesting little involvement of calcium-activated potassium currents, at least under our recording conditions.

\section{Potassium currents in basket cell nerve terminals}

Our results thus far revealed that $\alpha$-DTX (and other dendrotoxin homologs; data not shown) dramatically increases GABA release from basket cells and that this appears not to be mediated by changes in the amplitude of the potassium current in basket cell somata. Previous immunohistochemical studies suggested that DTX-sensitive potassium channels were likely to be present at high density in the terminations of basket cells; we therefore undertook to record potassium current directly from basket cell terminals.

Using DIC optics, basket cell presynaptic terminals can be distinguished as slender processes wrapping around both the 
Table 1. Pharmacology of basket cell somatic potassium current

\begin{tabular}{lcccc} 
& & \multicolumn{2}{c}{$\%$ of control } & \\
\cline { 3 - 4 } Blocker & Concentration & $\begin{array}{l}\text { Peak current } \\
\text { (mean } \pm \text { SEM) }\end{array}$ & $\begin{array}{l}\text { Steady-state current } \\
\text { (mean } \pm \text { SEM) }\end{array}$ & $n$ (number of cells) \\
\hline TEA & $10 \mathrm{~mm}$ & $25.9 \pm 3.9$ & $23.5 \pm 3.4$ & 9 \\
TEA & $30 \mathrm{~mm}$ & $14.7 \pm 2.7$ & $10.2 \pm 2.1$ & 7 \\
4AP & $1 \mathrm{~mm}$ & $100.2 \pm 0.1$ & $100.3 \pm 0.4$ & 4 \\
4AP & $5 \mathrm{mM}$ & $99.9 \pm 3.0$ & $100.4 \pm 3.0$ & 4 \\
Toxin I & $200 \mathrm{nM}$ & $92.7 \pm 2.7$ & $94.6 \pm 4.1$ & 4 \\
Toxin K & $200 \mathrm{nM}$ & $96.7 \pm 1.3$ & $97.2 \pm 1.1$ & 4 \\
Apamin & $1 \mu \mathrm{M}$ & $88.5 \pm 3.2$ & $93.7 \pm 6.3$ & 3 \\
CTX & $100 \mathrm{nM}$ & $93.4 \pm 2.5$ & $93.1 \pm 2.5$ & 4 \\
$\alpha$-DTX & $200 \mathrm{nM}$ & $92.7 \pm 1.3$ & $94.5 \pm 2.1$ & 5 \\
\hline
\end{tabular}

CTX, Charybdotoxin.
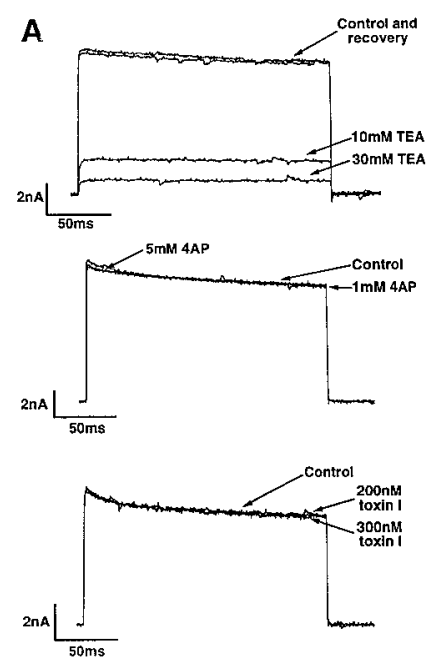

B
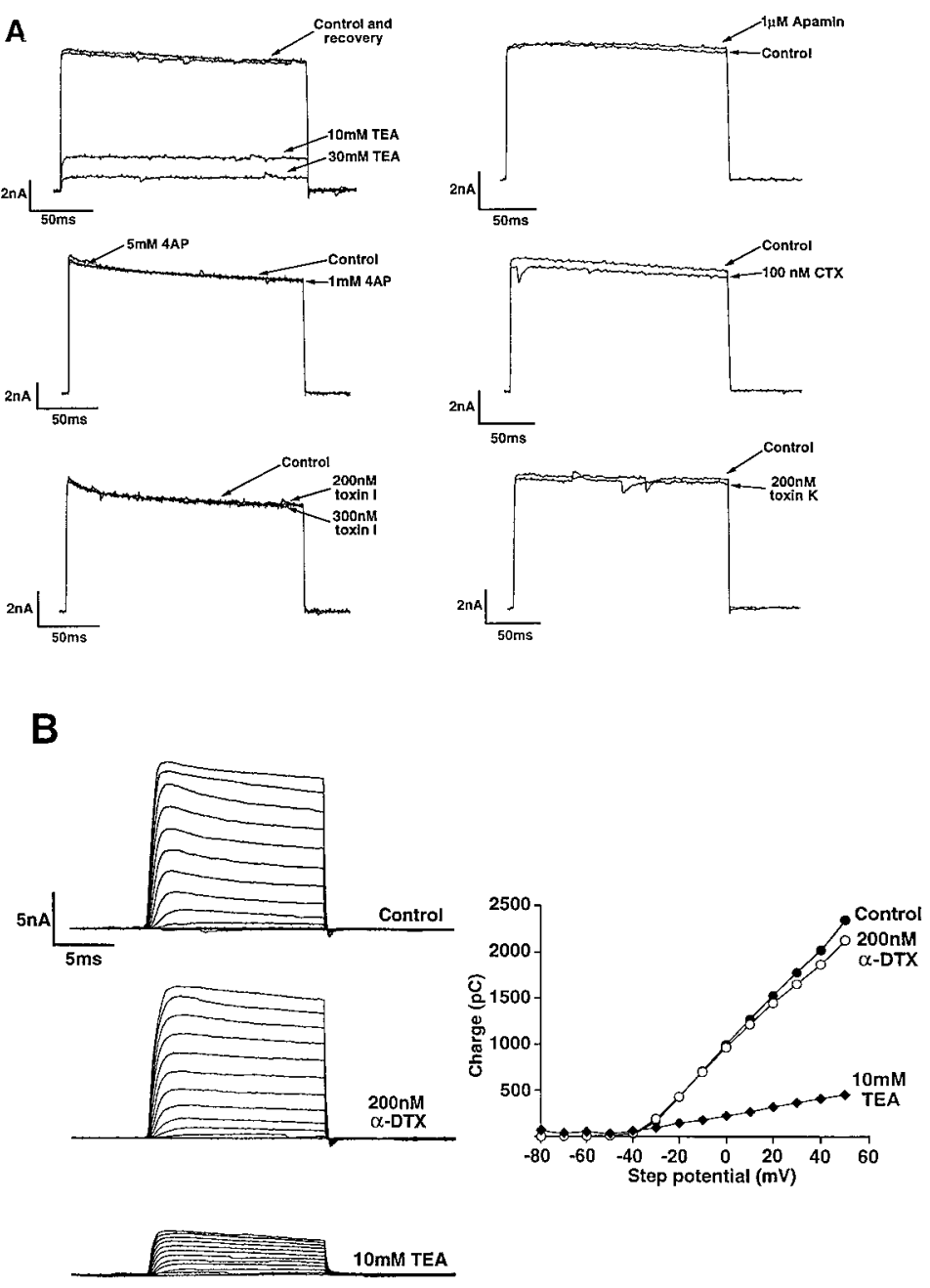

Figure 3. Pharmacology of basket cell somatic potassium currents. $A$, Basket cells were voltage-clamped at $-90 \mathrm{mV}$ and stepped to +30 $\mathrm{mV}$ with $200 \mathrm{msec}$ depolarizing voltage pulses. Significant reduction of the resulting somatic current was observed only after perfusion of 10 and $30 \mathrm{~mm}$ TEA (also see Table 1). $B$, The basket cell somatic current was also resistant to $\alpha$-DTX (see inset). The current-voltage plot shows data from the same cell; subsequent perfusion of $10 \mathrm{~mm}$ TEA substantially reduces the outward current.
Purkinje cell body and their axon initial segment. The combined DIC/fluorescence image presented in Figure $4 A$ shows a lucifer yellow-labeled basket cell terminal overlying a Purkinje cell soma and the brightly fluorescing back-labeled basket cell soma in the molecular layer. The cell was loaded with lucifer yellow during whole-cell recording from the exposed terminal at the point indicated on the figure. The axon connecting the soma and the terminal drops below the plane of focus and is not visible in Figure $4 A$. Nevertheless, the fluorescence image montage from the same experiment (Fig. 4B) clearly shows the distinctive basket cell morphology of a terminal wrapping around Purkinje cell somata. It also illustrates the extent to which the lucifer yellow label retrogradely travels during a short recording session $(\sim 10$ min in Fig. $4 B$ ). Figure $4 C$ shows another terminal fill at higher magnification; in this instance the recording electrode is still in place. Note how the basket cell terminal is strongly fluorescent, whereas the Purkinje cell soma that it wraps around remains unlabeled. Such unambiguous basket cell labeling has been ob- 

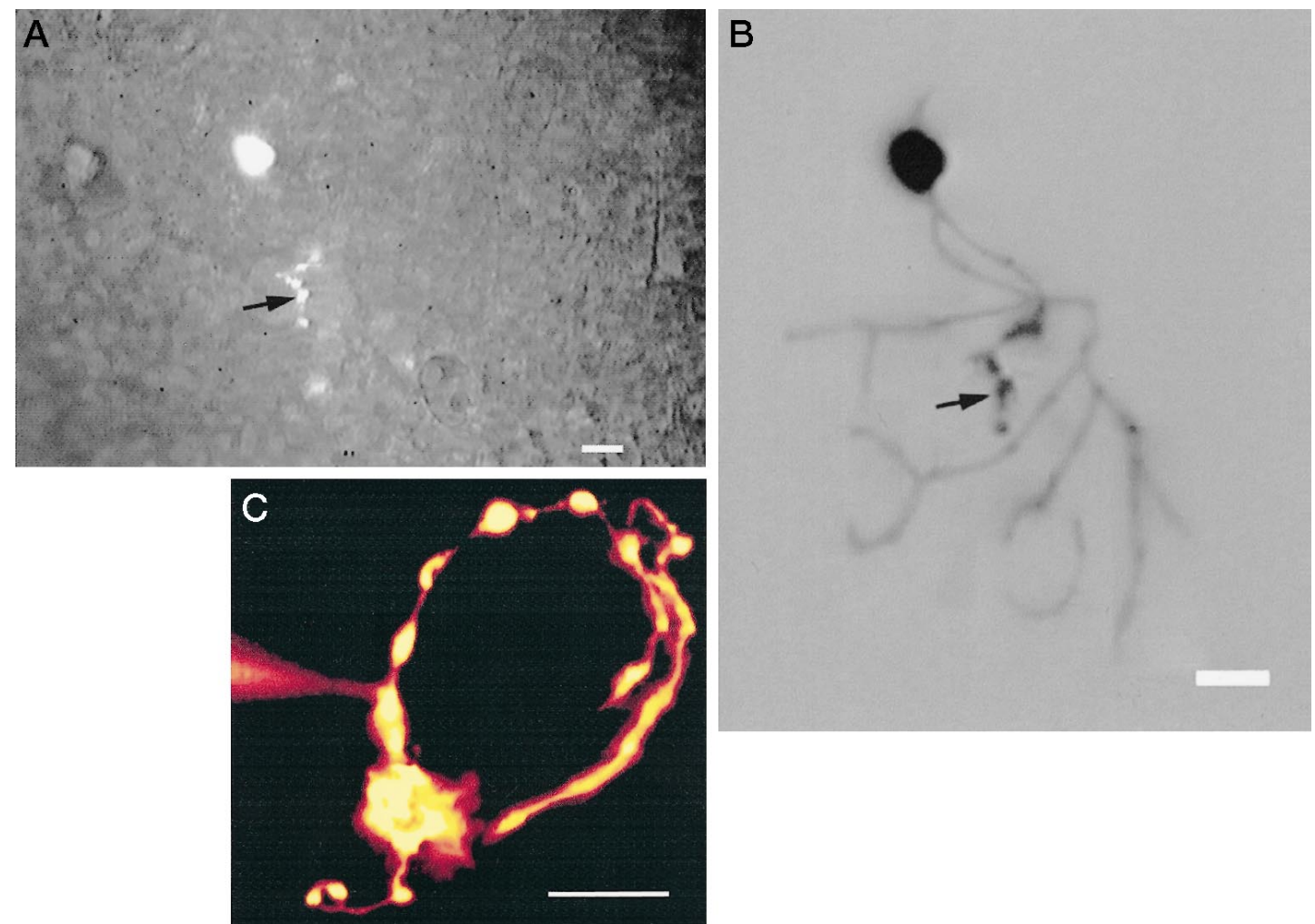

Figure 4. Retrograde labeling of basket cells. $A$, The identity of all nerve terminal recordings was confirmed by fluorescence imaging. This combined DIC/fluorescence image shows a brightly fluorescing basket cell nerve terminal overlying a Purkinje cell and the basket cell soma in the molecular layer. The arrow denotes the recording site. Scale bar, $10 \mu \mathrm{m}$. B. Fluorescence montage of the same cell, constructed from images captured at different focal planes. The nerve terminal is clearly connected to the soma, and additional terminal processes wrapping around Purkinje cells are visible. The arrow denotes the recording site. Scale bar, $10 \mu \mathrm{m}$. $C$, Close-up of a different basket cell nerve terminal fluorescence image. In this montage the recording electrode is still in position. Note how the terminal process outlines the underlying Purkinje cell and is highly fluorescent at the axon initial segment region. Scale bar, $10 \mu \mathrm{m}$.

served 34 times and comprises the 16 cell-attached and 8 wholecell recordings presented below; the remaining 10 were excluded from subsequent analysis because of unstable baseline/series resistance. Unintentional recordings from Bergmann glial cells or parallel/climbing fibers were encountered only three times during nerve terminal-directed recordings; two glial cells had no immediately obvious voltage-activated currents, whereas the "ascending" fiber had robust inward and outward currents.

All of the electrophysiology presented below is from processes that were subsequently identified as basket cell terminals by UV fluorescence.

\section{Cell-attached recording from basket cell terminals}

In the cell-attached recording configuration, patches from basket cell terminals exhibited both spontaneous action currents and voltage-activated currents.

At a patch holding potential of $0 \mathrm{mV}$ relative to the terminal resting potential, spontaneous action currents were observed in 12 terminals (total, $n=16$ ). These currents presumably reflect intermittent firing of basket cells; the mean frequency of such currents was $12.9 \pm 3.8 \mathrm{~Hz}$ (range, $1.3-35.8 \mathrm{~Hz} ; n=12$ ).

From a patch holding potential of $-30 \mathrm{mV}$ (relative to the basket terminal resting potential), $+10 \mathrm{mV}$ incremental voltage steps induced a fast inactivating inward current (threshold approximately $+10 \mathrm{mV}$ relative to the resting potential) and a more sustained outward current (threshold approximately $+30 \mathrm{mV}$ relative to the resting potential) (Fig. $5 A)(n=6)$. Mean ampli- tude of the outward current on a depolarizing step from -30 to $+90 \mathrm{mV}$ (relative to resting potential) was $75.4 \pm 15.8 \mathrm{pA}$ (range, 28-154 pA; $n=6$ ). The fast inward current seen on depolarization was eliminated when the patch was held at a potential of 0 $\mathrm{mV}$, presumably because of steady-state inactivation.

The outward current was sensitive to the potassium channel blocker 4-AP; during a depolarizing voltage step from a patch potential of -30 to $+80 \mathrm{mV}, 5 \mathrm{~mm} 4$-AP reduced the "steadystate" outward current by $70.1 \pm 1.7 \%(n=3)$. The block by $4-A P$ was rapid in onset (within $10 \mathrm{sec}$ ) and slowly reversible.

\section{Whole-cell recording from basket cell terminals}

In additional experiments it was possible to carry out whole-cell recordings from identified basket cell terminals. In these experiments, depolarizing voltage steps (200 msec long/10 mV increments) from a terminal holding potential of $-90 \mathrm{mV}$ evoked substantial outward currents with an activation threshold of approximately $-50 \mathrm{mV}$ (Fig. $5 \mathrm{C}$ ); the mean peak amplitude during this long step to $+30 \mathrm{mV}$ was $1.6 \pm 0.1 \mathrm{nA}$ (range, $1.3-2.4 \mathrm{nA}$; $n=8$ ). The currents inactivated slightly during the step; mean current amplitude at $200 \mathrm{msec}$ was $1.2 \pm 0.13 \mathrm{nA}$.

During a voltage step from -90 to $+30 \mathrm{mV}, 200 \mathrm{nM} \alpha$-DTX blocked $32.4 \pm 4.8 \%$ of the charge transfer $(n=3)$ (Fig. $5 C, D)$. The block was rapid in onset, taking 1-2 min to reach steady state, but was poorly reversible over the time period examined (Fig. $5 D$ ).

Taken together, these results are consistent with DTX- and 

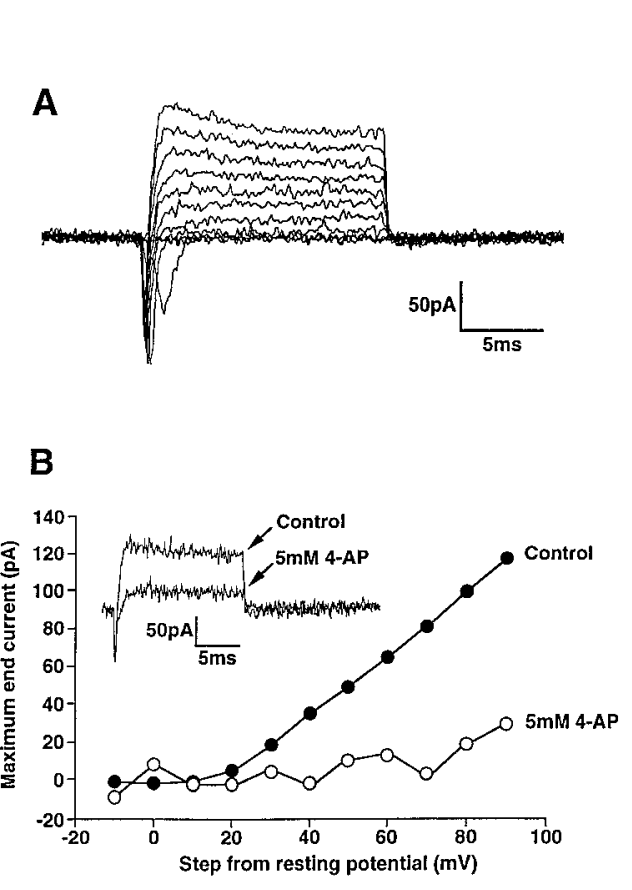

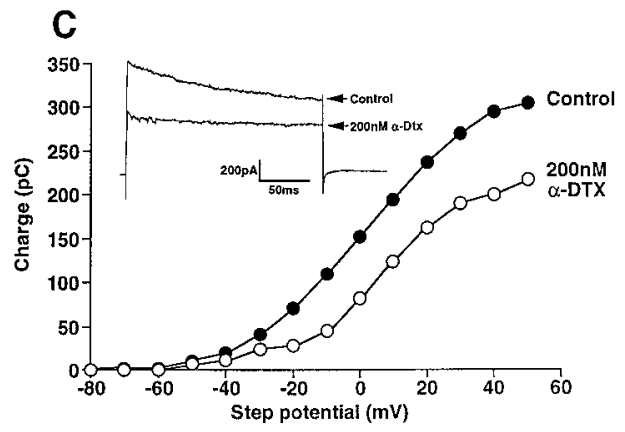

D

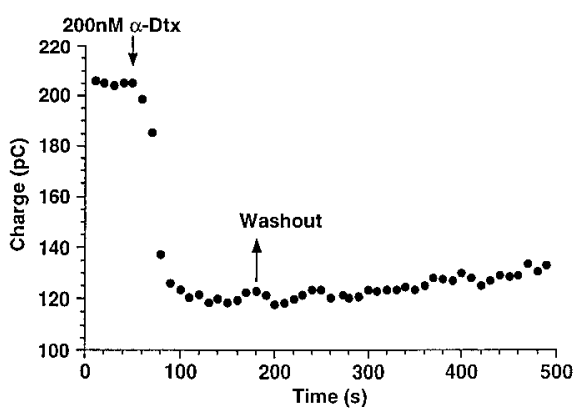

Figure 5. Voltage-gated currents in basket cell nerve terminals. $A$, Family of currents in the cell-attached configuration exhibiting a fast inward sodium current and a more sustained outward current. $B$, The outward current was sensitive to the broad spectrum potassium channel blocker 4-AP. $C$, In the whole-cell recording configuration, $\alpha$-DTX reduced basket cell nerve terminal potassium currents. $D$, The $\alpha$-DTX block of nerve terminal current was fast in onset and slow to wash out.
4-AP-sensitive potassium channels being preferentially localized to cerebellar basket cell presynaptic terminals.

\section{DISCUSSION}

In this study we have combined electrophysiological and fluorescence techniques to explore the role of certain voltage-gated potassium channels in modulating GABA release from cerebellar basket cells. Our novel preparation allows, for the first time, direct electrophysiological recordings from a mammalian CNS inhibitory synaptic terminal.

Immunohistochemical evidence reveals an extremely dense clustering of Kv1.2 channel $\alpha$-subunits in basket cell nerve terminal processes. These channels are confined to neuronal and not glial cells (McNamara et al., 1993) and are colocalized with antibodies identifying GABAergic terminals (Wang et al., 1993), which suggests that they play a crucial role in the modulation of cerebellar inhibitory transmission. This pattern of potassium channel expression in basket cells is particularly interesting, because in heterologous expression systems both Kv1.1 and Kv1.2 channels exhibit sensitivity to the DTX family of potassium channel blockers (Stühmer et al., 1989; Grissmer et al., 1994), whereas Kv3.4 does not (Vega-Saenz de Miera et al., 1994). High-density expression of DTX-sensitive channels in a well defined anatomical location offers an excellent opportunity to investigate the role of voltage-gated potassium channels in an important mammalian CNS inhibitory synapse.

Blockage of $\alpha$-DTX-sensitive potassium channels resulted in a dramatic increase in both the number and amplitude of spontaneous IPSCs in Purkinje cells, whereas IPSC rise and decay time constants remained unchanged, indicating a presynaptic site of action. To determine the precise site of action for $\alpha$-DTX, it was necessary to directly record potassium currents in both basket cell soma and nerve terminal regions. Recording from basket cell somata was straightforward, and our fluorescence images revealed morphology consistent with classic anatomical studies (Ramón y Cajal, 1911; Palay and Chan-Palay., 1974).

Detailed pharmacological analyses of the voltage-activated cur- rents of inhibitory interneurons in the mammalian CNS are uncommon. However, Zhang and McBain (1995a) dissected out components of voltage-activated $\mathrm{K}^{+}$current in the soma of hippocampal interneurons, revealing a fast, 4-AP-sensitive, DTXinsensitive A-type current, and a slower, delayed rectifier sensitive to TEA in the millimolar range (also DTX insensitive). In hippocampal interneurons, calcium-activated potassium currents were also shown to play a major role in modulating firing (Zhang and McBain, 1995b); in cerebellar basket cells we found little effect of selective blockers of such currents. Some authors have detected antibody labeling to Kv1.1 and Kv1.2 in the basket cell soma in the rat (Rhodes et al., 1995; Veh et al., 1995; McNamara et al., 1996); however, in other studies the soma exhibited no immunoreactivity [Wang et al., 1994 (mouse); Sheng et al., 1994 (rat)]. These differences may be dependent on the age of the animal, species differences, or inconsistencies between the peptide sequences used to raise antibodies (Rhodes et al., 1996). The total lack of effect of DTX homologs on the basket cell somatic current, at concentrations where we observed marked enhancements of IPSCs in Purkinje cells, is consistent with a complete absence of functional Kv1.1 or Kv1.2 channels in the somatic membrane of mouse basket cells. To determine whether functional DTX-sensitive channels exist in basket cell nerve terminal compartments, we examined directly the voltage-gated currents in identified terminals. These recordings were considerably more difficult to obtain than the somatic recordings. Nevertheless, we achieved an acceptable success rate and obtained high quality cell-attached and whole-cell electrophysiological measurements, with fluorescence images unambiguously confirming the distinctive basket cell morphology. Initial cell-attached recording revealed spontaneous action currents and voltage-activated currents. The fast inactivating inward current had the characteristics of a Na${ }^{+}$current. Voltage-activated, TTX-sensitive $\mathrm{Na}^{+}$current has also been found at the only other mammalian presynaptic terminal studied thus far, the "giant" glutamatergic calyx of Held (Forsythe, 1994; Borst et al., 1995). These results suggest that 
action potentials may be reliably transmitted to release sites for both inhibitory and excitatory neurotransmitters. From the present study, $\mathrm{Na}^{+}$channels appear to be present at a considerable density in basket cell terminals. Using the empirical formula of Sakmann and Neher (1983) for calculating patch area from electrode resistance, we arrive at a figure of $38 \mathrm{pA} / \mu \mathrm{m}^{2}$ for $\mathrm{Na}^{+}$ channels in basket cell terminals; this compares with values of 8.3 and $1.3 \mathrm{pA} / \mu \mathrm{m}^{2}$ for $\mathrm{Na}^{+}$channel density on Purkinje cell soma and dendrites, respectively (Stuart and Häusser, 1994).

A possible explanation for the substantial $\mathrm{Na}^{+}$currents in basket cell terminals may be that they ensure action potential propagation into the terminal region in the face of an unfavorable shunt because of the increased membrane area resulting from considerable terminal branching. Alternatively, there may exist a region of low impedance attributable to the channel complement in the terminal region, with large leak or high $\mathrm{K}$ conductances or both. The outward current was initially characterized as a potassium current because of its voltage sensitivity and inhibition by the potassium channel blocker 4-AP, which blocks a number of cloned potassium channels including Kv1.1 and Kv1.2 (Grissmer et al., 1994). The whole-cell terminal experiments revealed large outward currents in response to step depolarization and allowed us to use more specific $\mathrm{K}$ channel blockers. The sensitivity of this current to $\alpha$-DTX further supports the anatomical evidence for Kv1.1 and Kv1.2 $\alpha$-subunits being present in basket cell terminals. Additionally, the block of the terminal current by $\alpha$-DTX occurred over a time course comparable to that of the $\alpha$-DTXinduced enhancement of Purkinje cell IPSC frequency and amplitude, further substantiating the role of these channels in the modulation of neuronal excitability. DTX blocks Kv1.1 and Kv1.2 homomeric channels with nanomolar potency in expression studies (Chandy and Gutman, 1995); however, 200 nм $\alpha$-DTX blocked only $\sim 30 \%$ of the total outward current in basket cell terminals. Further work will be necessary to dissect out possible contributions from other $\operatorname{Kv} \alpha$ and $\operatorname{Kv} \beta$ subunits. Furthermore, pharmacological properties of heteromultimeric channels can be quite different from homomultimers, and great caution is required when extrapolating from channel properties in simple expression systems to native tissues; indeed, one of the aims of the present study is to determine how valid such extrapolations are.

DTX-sensitive K channels are selectively localized to basket cell axonal terminals that contribute a significant proportion of the terminal potassium current. Recently, a study by Hoffman et al. (1997) demonstrated similar preferential sorting of DTXinsensitive, A-type $\mathrm{K}^{+}$channels in the dendrites of hippocampal pyramidal cells, the density of which increases with distance from the cell soma. Immunohistochemical studies suggest that these A-type channels are composed of Kv4.2 subunits; the specific localization of these channels results in a dampening effect on dendritic excitability. Furthermore, a recent study (Llano et al., 1997) has shown that there is a marked spatial heterogeneity of $\mathrm{Ca}^{2+}{ }_{\mathrm{i}}$ changes in basket cells during depolarization, with greater changes in discrete spots in axonal and terminal regions than in somatic or dendritic compartments, presumably reflecting preferential membrane targeting of calcium channels to distinct cellular regions. Therefore, the functional responses of central neurons must depend on both the complement and the targeting of specific ion channels to precisely defined locations within the cell membrane. Our experiments have demonstrated discrete compartmentalization of functional DTX- and 4-AP-sensitive potassium channels to basket cell nerve terminals, which suggests that these channels play a crucial role in controlling cerebellar inhibition.

\section{REFERENCES}

Altman J (1982) Morphological development of the rat cerebellum and some of its mechanisms. Exp Brain Res [Suppl] 6:8-49.

Andersen P, Eccles J, Voorhoeve PE (1963) Inhibitory synapses on somas of Purkinje cells in the cerebellum. Nature 199:655-656.

Bishop GA (1993) An analysis of HRP-filled basket cell axons in the cat's cerebellum i. Morphometry and configuration. Anat Embryol 188:287-297.

Borst JGG, Sakmann B (1996) Calcium influx and transmitter release in a fast CNS synapse. Nature 383:431-434.

Borst JGG, Helmchen F, Sakmann B (1995) Pre- and postsynaptic whole-cell recordings in the rat medial nucleus of the trapezoid body of the rat. J Physiol (Lond) 489:825-840.

Chandy KG, Gutman GA (1995) Voltage-gated potassium channel genes. In: Handbook of receptors and channels (North RA, ed) pp 171. Boca Raton, FL: CRC.

Clark BA, Barbour B (1997) Currents evoked in Bergmann glial cells by parallel fibre stimulation in rat cerebellar slices. J Physiol (Lond) 502:335-350.

Eccles JC, Ito M, Szentágothai J (1967) The cerebellum as a neuronal machine. New York: Springer.

Forsythe ID (1994) Direct patch recording from identified presynaptic terminals mediating glutamatergic EPSCs in the rat CNS, in vitro. J Physiol (Lond) 479:381-387.

Grissmer S, Nguyen AN, Aiyar J, Hanson DC, Mather RJ, Gutman GA, Karmilowicz MJ, Auperin DD, Chandy KG (1994) Pharmacological characterization of five cloned $\mathrm{K}^{+}$channels, types Kv1.1, 1.2, 1.3, 1.5 and 3.1, stably expressed in mammalian cell lines. Mol Pharmacol 45:1227-1234.

Hoffman DA, Magee JC, Colbert CM, Johnston D (1997) $\mathrm{K}^{+}$channel regulation of signal propagation in dendrites of hippocampal pyramidal neurons. Nature 387:869-875.

Kistner U, Wenzel BM, Veh RW, Caes-Langhoff C, Garner AM, Appeltauer U, Voss B, Gundelfinger ED, Garner CC (1993) SAP90, a rat presynaptic protein related to the product of the Drosophila tumor suppressor gene dlg-A. J Biol Chem 268:4580-4583.

Larramendi LM (1969) Analysis of synaptogenesis in the cerebellum of the mouse. In: Neurobiology of cerebellar evolution and development (Llinas R, ed), pp 803-843. Chicago: American Medical Association.

Laube G, Röper J, Pitt JC, Sewing S, Kistner U, Garner CC, Pongs O, Veh RW (1996) Ultrastructural localization of Shaker-related potassium channel subunits and synapse-associated protein 90 to septate-like junctions in rat cerebellar Pinceaux. Mol Brain Res 42:51-61.

Llano I, Tan YP, Caputo C (1997) Spatial heterogeneity of intracellular $\mathrm{Ca}^{2+}$ signals in basket cells from rat cerebellar slices. J Physiol (Lond) 502:509-519.

McNamara NMC, Muniz ZM, Wilkin GP, Dolly JO (1993) Prominent location of a $\mathrm{K}^{+}$channel containing the $\alpha$-subunit Kv1.2 in the basket cell nerve terminals of rat cerebellum. Neuroscience 57:1039-1045.

McNamara NMC, Averill S, Wilkin GP, Dolly JO, Priestley JV (1996) Ultrastructural localization of a voltage-gated $\mathrm{K}^{+}$channel $\alpha$-subunit (Kv1.2) in the rat cerebellum. Eur J Neurosci 8:688-699.

Müller T, Fritschy JM, Grosche J, Prat GD, Mohler H, Kettenman H (1994) Developmental regulation of voltage-gated K channel and $\mathrm{GABA}_{\mathrm{a}}$ receptor expression in Bergmann glial cells. J Neurosci 14:2503-2514.

Palay SL, Chan-Palay V (1974) Cerebellar cortex. Cytology and organization. Berlin: Springer.

Ramón y Cajal S (1911) Histology of the nervous system of man and vertebrates (translators, Swanson N, Swanson L). Oxford: Oxford UP, 1995.

Rhodes KJ, Keilbaugh SA, Battezueta NX, Lopez KL, Trimmer JS (1995) Association and colocalization of $\mathrm{K}^{+}$channel $\alpha$ - and $\beta$-subunit polypeptides in rat brain. J Neurosci 15:5360-5371.

Rhodes KJ, Monaghan MM, Barrezueta NX, Nawoschick S, BekeleArcuri Z, Matos MF, Nakahira K, Schechter LE, Trimmer JS (1996) Voltage-gated $\mathrm{K}^{+}$channel $\beta$ subunits: expression and distribution of $\operatorname{Kv} \beta 1$ and $\operatorname{Kv} \beta 2$ in adult rat brain. J Neurosci 16:4846-4860.

Sakmann B, Neher E (1983) Geometric parameters of pipettes and membrane patches. In: Single channel recording (Sakmann B, Neher E, eds), pp 37-59. New York: Plenum.

Sheng M, Tsaur M-L, Jan YN, Jan LY (1992) Subcellular segregation of 
two A-type $\mathrm{K}^{+}$channel proteins in rat central neurones. Neuron 9:271-284.

Sheng M, Tsaur M-L, Jan YN, Jan LY (1994) Contrasting subcellular localization of the $\mathrm{mKv} 1.2 \mathrm{~K}^{+}$channel subunit in different neurons of rat brain. J Neurosci 14:2408-2417.

Stuart G, Hausser M (1994) Initiation and spread of sodium action potentials in cerebellar Purkinje cells. Neuron 13:703-712.

Stuart GJ, Dodt H-U, Sakmann B (1993) Patch-clamp recordings from the soma and dendrites of neurons in brain slices using infrared microscopy. Pflügers Arch 423:511-518.

Stühmer W, Ruppersberg JP, Schröter KH, Sakmann B, Stocker M, Giese KP, Perschke A, Baumann A, Pongs O (1989) Molecular basis of functional diversity of voltage-gated potassium channels in mammalian brain. EMBO J 8:3235-3244.

Vega-Saenz de Miera E, Weiser M, Kentros C, Lau D, Moreno H, Serodio P, Rudy B (1994) Shaw-related $\mathrm{K}^{+}$channels in mammals. In: Handbook of membrane channels (Peracchia C, ed), pp 41-78. New York: Academic.

Veh RW, Lichtinghagen R, Sewing S, Wunder F, Grumbach IM, Pongs O (1995) Immunocytochemical localization of five members of the Kv1 channel subunits: contrasting subcellular locations and neuron-specific colocalizations in rat brain. Eur J Neurosci 7:2189-2205.
Vincent P, Armstrong CM, Marty A (1992) Inhibitory synaptic currents in rat cerebellar Purkinje cells: modulation by postsynaptic depolarization. J Physiol (Lond) 456:453-471.

Wang H, Kunkel DD, Martin TM, Schwartzkroin PA, Tempel BL (1993) Heteromultimeric $\mathrm{K}^{+}$channels in terminal and juxtaparanodal regions of neurons. Nature 365:75-79.

Wang H, Kunkel DD, Schwartzkroin PA, Tempel BL (1994) Localization of Kv1.1 and Kv1.2, two K channel proteins, to synaptic terminals, somata, and dendrites in the mouse brain. J Neurosci 14:4588-4599.

Weiser M, Vega-Saenz De Miera E, Kentros C, Moreno H, Franzen L, Hillman D, Baker H, Rudy B (1994) Differential expression of Shawrelated $\mathrm{K}^{+}$channels in the rat central nervous system. J Neurosci 14:949-972.

Zhang LM, Goldman JE (1996) Generation of cerebellar interneurons from dividing progenitors in white matter. Neuron 16:47-54.

Zhang LM, McBain CJ (1995a) Voltage-gated potassium currents in striatum-alveus inhibitory neurones of the rat CA1 hippocampus. J Physiol (Lond) 488:647-660.

Zhang LM, McBain CJ (1995b) Potassium conductances underlying repolarisation and afterhyperpolarisation in rat CA1 hippocampal interneurones. J Physiol (Lond) 488:661-672. 